Revue Française de Civilisation Britannique

XIV-1 | 2006

La dévolution des pouvoirs à l'Écosse et au Pays de Galles 1966-1999

\title{
Devolution and Britishness, 1966-1999
}

La dévolution et l'identité britannique, 1966-1999

\section{Paul Ward}

\section{OpenEdition}

1 Journals

Electronic version

URL: http://journals.openedition.org/rfcb/1159

DOI: $10.4000 /$ rfcb. 1159

ISSN: 2429-4373

Publisher

CRECIB - Centre de recherche et d'études en civilisation britannique

\section{Printed version}

Date of publication: 2 January 2006

Number of pages: 11-18

ISBN: 2-911580-23-0

ISSN: 0248-9015

Electronic reference

Paul Ward, « Devolution and Britishness, 1966-1999 », Revue Française de Civilisation Britannique [Online], XIV-1 | 2006, Online since 15 October 2016, connection on 19 April 2019. URL : http:// journals.openedition.org/rfcb/1159; DOI : 10.4000/rfcb.1159

\section{(c) (i) $\ominus$}

Revue française de civilisation britannique est mis à disposition selon les termes de la licence Creative Commons Attribution - Pas d'Utilisation Commerciale - Pas de Modification 4.0 International. 


\title{
Devolution and Britishness, 1966-1999
}

\author{
Paul WARD \\ University of Huddersfield
}

In 1966 Plaid Cymru (the Party of Wales) won their first parliamentary seat. The following year, the Scottish National Party defeated the Labour Party in a byelection in Hamilton, Scotland. In May 1999 a national assembly was established in Cardiff and a parliament was formed in Edinburgh. In only three decades the political integrity of the unitary British state, it seemed, had been undermined. This has made the theme of Britishness, quite simply defined as what it means to be a Briton, a central subject of political, sociological, cultural and historical discussion. Hardly a week passes without a further contribution to these discussions with great emphasis being placed on the sense of crisis in what it means to be British. In 1977 Tom Nairn, a left-wing Scottish nationalist, published his seminal book, The BreakUp of Britain, setting the tone for much subsequent discussion. ${ }^{1}$ There was a staggering array of reasons for supposing that Britain was in its death throes from the 1960s onwards. The nationalism of Plaid and the SNP developed further support against the backdrop of the revival of 'the Troubles' in Northern Ireland after 1969 (3,000 people were killed in the three decades up to the Good Friday Agreement of 1998). There were also hints of regionalism in some parts of England, such as Cornwall and the north east. The monarchy, so long a core part of the nation, was going through troubled times, including the failure of the marriages of three out of four of the Queen's children. And the sovereignty of the monarch was being diluted by integration into the European Union, an unavoidable outcome of the loss of the British Empire and the relative decline of the British economy. A further legacy of Empire was the mass migration of people from the former colonies to the metropolis, so that by 1999 around six per cent of the population defined themselves as not being white. A wider development was that the advance of consumer capitalism which brought forth the threat of the Americanisation of British culture, enhanced because the USA shared the same language as the United Kingdom. In the early and mid-twentieth century it had seemed that being British was settled and stable yet from the late 1960s on all that was solid was melting into the air.

Devolution to Scotland and Wales has been the most measurable part of this crisis of Britishness. It is identifiable in legislation, with repercussions in political and civil society. Many commentators consider that devolution is part of a continuing process, the start of further division within the United Kingdom. This rests on the assumption that it is difficult for more than one nation to reside within a single polity and that devolution was an inevitable outcome of divergence. This

${ }^{1}$ Tom NAIRN, The Break-Up of Britain: Crisis and Neo-nationalism, London: New Left Books, 1977, (second edition, London: Verso, 1981). Other books with similar themes, but written by Conservatives, include John REDWOOD, The Death of Britain? Basingstoke: Macmillan, 1999 and Peter HITCHENS, The Abolition of Britain, London: Quartet, 1999. 
essay intends to examine the relationship between devolution and Britishness across the three decades from the 1960s to the 1990s, arguing that the consequences have not been an unravelling of the United Kingdom in this period but a remarkable ability of Britishness to adapt itself to changing circumstances in Wales and Scotland. Divergence does not have to lead to dissolution. The essay argues that devolution needs to be considered in a historical light, not as the outcome of a sudden crisis in late twentieth-century Britain but as part of the continuing diversity of the United Kingdom, which provided models on which the accommodation of resurgent Welshness and Scottishness could be based.

\section{The national crisis in the 1960s and 1970s}

The 1960s was a period of immense change, for Britain as much as continental Europe and the United States. Many of the challenges to Britishness mentioned in the introduction came to a head in the decade. Hence decolonisation developed from a trickle into a deluge. In Africa alone, Nigeria, Sierra Leone, Tanzania, Uganda, Kenya, Malawi, Zambia, Gambia, Botswana, Lesotho and Swaziland became independent between 1960 and 1968, effectively bringing to an end Britain's imperial status. In 1968 the Labour government decided to extract Britain from a global role by announcing the accelerated withdrawal of most military forces from 'east of Suez'. Therefore, the internal resurgence of nationalism seemed part of a wider crisis of the British state in global context. In particular there was a visible campaign in Wales to defend the Welsh language, since by 1961 the proportion of Welsh speakers was down to a quarter of the population (from half in 1900). In 1964 Labour returned to government after thirteen years in opposition, and reliant on support from Scotland and Wales, responded to evidence of nationalism by establishing a Cabinet level minister responsible for Wales with a specific department known as the Welsh Office. Labour had gone through a substantial period of opposition to devolution in the 1940s and 1950s because centralised planning seemed to offer the best method of securing social reform and economic growth. However, the weakness of British industrial productivity was greatest in Scotland and Wales (and Northern Ireland) despite Labour's attempts to support regional growth within a nationally directed economy. Many of the party's workingclass supporters in Wales and Scotland, while not turning to nationalism, were becoming disillusioned. Leading Labour figures therefore viewed the election of a handful of nationalists in Wales and Scotland with an exaggerated sense of foreboding. In 1967 the government passed the Welsh Language Act, which gave Welsh equal legal status with English and in 1969 it organised the investiture of Prince Charles as Prince of Wales at Caernarfon castle. It also appointed the Crowther (later Kilbrandon) commission to consider devolution. The advantage of the commission was that it showed that Labour was doing something - but it would take years to report. The fact that the expected nationalist breakthrough failed to materialise in the 1970 general election, in both Wales and Scotland, suggested that these tactics had worked, though Labour lost the election to the Conservatives.

However, continuing economic weakness ensured that voters would persist in looking for ways to protest against the failure of the two main parties to protect British industry against global economic recession exacerbated by the oil crisis of 1973. From a low point of 20,000 votes in 1951, the SNP and Plaid Cymru 
combined were able to secure a million votes in the general election of October 1974. The discovery of oil in the North Sea allowed the SNP to claim 'It's Scotland's oil!' providing them with the argument that an independent Scotland had become economically viable. In this particular circumstance the SNP were able to make a major advance. In 1974 thirty per cent of Scottish voters supported them and the party won eleven of Scotland's seventy-one seats. Whereas the 1960s had seemed a decade of optimism - with Britain contributing extensively to a cultural renaissance led by youth - the 1970s seemed to offer nothing but crisis upon crisis. ${ }^{2}$ Political dealignment made for unstable politics, there was a wave of industrial unrest so that strikes were described as 'the British disease', immigration in a period of unemployment allowed racist politicians to emerge from the shadows, and even the Queen's Silver Jubilee in 1977 was spoiled by the Sex Pistols' version of 'God Save the Queen' reaching number two in the pop music charts.

\section{Responding to nationalism}

The response to the rise of nationalism added to crisis and pessimism. Labour had been re-elected in February 1974 without an overall majority and in October 1974 only achieved a majority of three. Therefore the party leaders had agreed to consider devolution under pressure from the Liberals and nationalists. ${ }^{3}$ The problem remained that there was no consensus on what path to take. Some people in all parties were prepared to consider devolution; even the Conservatives had established a constitutional committee in 1968 that had recommended an elected assembly in Scotland. But there were also determined opponents of devolution in all parties, and they were not all English. Hence the Scottish and Welsh Labour MPs Tam Dalyell and Neil Kinnock rejected arguments for devolution, as, temporarily in 1974, did the Labour Party's Scottish Council. When the Labour government introduced a devolution bill to Parliament in 1976, it was rejected. Increasingly reliant on the Liberals and nationalists, the government was forced to try again and separate Scotland and Wales Acts were passed in 1978. The Acts did not grant devolution to Scotland and Wales, but legislated to allow its introduction should referendums in those countries support the idea. On 1 March 1979 (St David's Day) eight out of ten of those who voted in Wales rejected devolution. In Scotland nearly 52 per cent voted for devolution but this was not more than the 40 per cent of the entire electorate specified by an amendment to the Scotland Act. Two months later the Labour government fell on a vote of no confidence supported by the Conservatives and Scottish Nationalists.

\section{Thatcherism and the Union}

Discussion of devolution therefore seemed part of the general decline of Britain at the end of the twentieth century. Britain was by now a member of the European Economic Community, was fighting an undeclared war in Northern Ireland, and saw a further wave of strikes in 1979 (known as the "winter of

${ }^{2}$ Richard WEIGHT, Patriots: National Identity in Britain 1940-2000, London: Pan, 2003.

${ }^{3}$ The Liberals had adhered to a devolution policy for much of their history. In Scotland the SNP had overtaken them as the third party in 1970 so the Liberals reasserted their devolution policy. 
discontent'). In such circumstances, the promise of Margaret Thatcher, the leader of the Conservative Party since 1975, to end the crisis and make Britain great again had great resonance, especially in England but also in Scotland and Wales. In May 1979 Thatcher, English to the core and Unionist through and through, was elected with an overall majority of forty-three seats in the House of Commons. Firm government was once more possible after years of small or non-existent parliamentary majorities. In Scotland and Wales the vote of the nationalist parties collapsed. Thatcher's success, despite massive unemployment, can be measured by a survey that suggested that 86 per cent of those living in Britain were proud to be British. Richard Rose, the widely respected political scientist who conducted the survey, argued that 'Because national pride is so widespread in Britain, it is normal in the literal sense, that is, it is the norm to which nearly everyone conforms. ${ }^{94}$ And this was before the successful re-conquest of the Falkland Islands following the Argentinean invasion of 1982, after which Thatcher declared 'We have ceased to be a nation in retreat. ${ }^{5}$

Yet the paradox was that Thatcher's British patriotic project was to contribute more to the unravelling of the United Kingdom than the decade-long crisis of the 1970s. Labour's hold on political loyalty had been under threat in Scotland and Wales because of the detrimental effect of economic decline in those nations and the availability of protest parties expressing nationalism, yet Labour had never seriously been challenged by the nationalists. In Wales (if 1983 is discounted) Labour's lowest share of the vote between 1945 and 1997 was 45 per cent and in Scotland it was 36 per cent. The nationalists' highest share was 11.5 per cent in Wales and 30 per cent in Scotland. More usually Labour could rely on about half the vote in Wales and more than 40 per cent in Scotland, whereas the nationalists' share after 1970 averaged only 18.8 per cent in Scotland and 9.4 per cent in Wales. Mainly this was because Labour had delivered on the promise of a welfare state after the Second World War. The socialisation of the state had been accomplished within a language of British nationalism. Its institutions were 'national' and 'British': the National Health Service, the National Coal Board, British Railways and National Insurance. The Scottish and Welsh contribution to Labour had been extensive from the years of the party's foundation and Aneurin (Nye) Bevan and James Griffiths from Wales and Tom Johnston from Scotland had ensured that the welfare state was British rather than English. It was little wonder that the Welsh-speaking trade union leader Huw T. Edwards could answer in the affirmative to the question 'Is the British way of life worth preserving?' because, he said in the early 1950s, 'We have seen built in our time ... the welfare state. ${ }^{6}$ Thatcher believed that dependence on the welfare state was a fundamental source of Britain's weakness. Her desire to 'roll back the frontiers of the state ${ }^{7}$, was particularly hard felt in Wales and Scotland for, as she

\footnotetext{
${ }_{5}^{4}$ Paul WARD, Britishness since 1870, London: Routledge, 2004, p. 8.

5 Margaret THATCHER, 'Speech to Conservative Rally at Cheltenham', 3 July 1982, http://www.margaretthatcher.org/speeches/displaydocument.asp?docid=104989, accessed 13 August 2006.

${ }^{6}$ Quoted in Paul WARD, Unionism in the United Kingdom, 1918-1974, Basingstoke: Palgrave, 2005, p. 114.

${ }^{7}$ Margaret THATCHER, 'Speech to the Conservative Party conference', 10 October 1986, http://www.margaretthatcher.org/speeches, accessed 19 October 2006
} 
noted in her memoirs, 'public expenditure per head in Scotland was far higher than in England' and hence, 'In short the conditions of dependency were strongly present.' 8 In undermining 'dependency' Thatcher was therefore undermining Britishness and, more disastrously, her party in Wales and Scotland. By 1997 no Conservatives were returned to parliament in either country. The inability of Scottish and Welsh voters to shape government policy certainly led to a renewed growth of nationalism. By the end of the 1980s around one in five voters in Scotland were supporting the SNP and Plaid had recovered much of its support in Wales. There was a widespread feeling that 'British' politics, dominated by the Conservatives, lacked legitimacy. In particular, the introduction of the Community Charge (known as the poll tax) to finance local authorities in Scotland a year before England and Wales suggested that Scotland could not even rely on equality of treatment within the Union.

\section{The recognition of pluralism in historical context}

This led to a resurgence of interest in the political representation of the distinctive national identities of Wales and Scotland. Yet much of this took place within the British parties - Labour and the Liberal Democrats. Support within Labour for constitutional reform at first looked like weakness, a response to SNP growth, yet Labour has gone through an 'intellectual reorientation'. John Smith, Donald Dewar and Gordon Brown were all sincere proponents of devolution and the party participated fully in the Scottish Constitutional Convention launched in 1989, contributing to the recommendation that a parliament with wide legislative powers be formed in Edinburgh. Labour benefited from nationalism in the 1980s and 1990s rather than being damaged by it.

This was not just a return to the 1970s for Scottish Labour but the revival of a longer tradition of pluralist Britishness within British politics of the left going back to the late nineteenth century. Acceptance of Irish Home Rule had been a central component of radical and socialist politics even before the conversion of William Gladstone to that policy in 1886. The recognition of national distinctiveness was seen as a policy for strengthening the Union of the United Kingdom, which was widely seen as a progressive force on the left. Hence Gladstone considered that 'the true supporters of the union are those who firmly uphold the supreme authority of parliament, but exercise that authority to bind the three nations by the indissoluble tie of liberal and equal laws. ${ }^{10}$ In the Edwardian period, the Liberals and Labour once more united behind Irish Home Rule and until the 1920s, Home Rule for Scotland and Wales had been important parts of the left's platform. In a distorted way, the pluralism of the United Kingdom had been recognised in the parliament devolved to Northern Ireland by the 1920 Government of Ireland Act. The existence of a parliament in Belfast recognised the variety of Britishness, though unintentionally this had proved to be a loyal and Protestant variety.

\footnotetext{
${ }^{8}$ Margaret THATCHER, The Downing Street Years, London: HarperCollins, 1993, p. 619.

${ }^{9}$ I.G.C. HUTCHISON, Scottish Politics in the Twentieth Century, Basingstoke: Palgrave 2001, pp. 149, 130.

${ }^{10}$ Eugenio BIAGINI, Gladstone, Basingstoke: Palgrave, 2000, p. 97.
} 
In each case, the British parties were responding to challenges from the 'periphery' but often those challenges came from within their own parties. Home Rule Bills were introduced for Scotland and Wales before the First World War by Liberals and in the inter-war years and after 1945 by Labour MPs, such as the Bill presented to the Commons by S.O. Davies in 1955. Neither the Liberals nor the Labour party were English parties. Both drew considerable strength from Scotland and Wales, and indeed many feared that devolution might lead to a reduction in the number of MPs sent by those nations to the House of Commons, making it harder for the left to form governments. In the late 1960s and 1970s Labour's interest in devolution was only aroused by the sense of electoral threat but the ability to respond to calls for constitutional change was created by the nature of Labour as a 'multi-national coalition party' that secured support in all parts of Britain. ${ }^{11}$ There were tensions between centralisation and devolution but Labour could respond, as the Liberals had once done, to demands for recognition of national diversity. Whereas nationalists called for independence, Labour could respond with suggestions for change that addressed the issue of what became known under Thatcher as 'the democratic deficit' in Wales and Scotland without the risk of the fragmentation of the United Kingdom.

\section{Labour and pluralism}

Labour was able to show, as had its predecessors, that the distinctiveness of Wales and Scotland could be expressed politically within the context of a multinational state. It was this organic connection of the party within Wales and Scotland which enabled it to deal with the notion of asymmetry, that Scotland wanted greater devolution of powers than Wales. A leading example was the timing of the referendums in 1997. It was widely known that support for change was substantial in Scotland and so the government held the referendum there on 11 September, a week ahead of that in Wales - allowing the large positive vote for devolution and taxraising powers to be known before Wales went to the polls on the following Thursday (18 September). Given that support for devolution in Wales was waferthin, only half the electorate voted and of them only 50.3 per cent supported the limited measure of devolution on offer, it might be said that timing was everything.

Furthermore, Labour's success can be judged in its performance in elections for the Scottish Parliament and Welsh Assembly. Despite some heavy-handed centralised intervention by the party leadership in London, Labour has maintained its leading position in both devolved nations. Held under a proportional system (unlike elections to the UK Parliament), the results reflected Labour strength (see Table 1).

In what amounts to a four-party system in Scotland, Labour held 43.5 per cent of the seats and in Wales 47 per cent of the seats. It can be argued from this that Labour represented the balance of national identities within the UK. A vote for Labour allowed expression of both British and Scottish/Welsh identities in politics.

${ }^{11}$ Eugenio BIAGINI (ed.), Citizenship and Community: Liberals, Radicals and Collective Identities in the British Isles, 1865-1931, Cambridge: Cambridge University Press, 1996, p 2. 
The recent conclusion by the Economic and Social Research Council's Devolution Project is that, while Britishness is declining, 'large majorities in all parts of Great Britain claim some level of Britishness: around three-quarters of the English and Welsh and around two-thirds of Scots'. ${ }^{12}$ In the second elections, held in 2003, while Labour fared less well, the decline in support for the nationalist parties was greater in both nations.

Table 1

\begin{tabular}{|c|c|c|}
\hline Elections 6 May 1999 & Scotland & Wales \\
\hline Labour & 56 & 28 \\
\hline SNP & 35 & - \\
\hline Plaid Cymru & - & 17 \\
\hline Conservative & 18 & 9 \\
\hline Liberal Democrat & 17 & 6 \\
\hline Others & 3 & - \\
\hline
\end{tabular}

\section{Conclusion}

Such evidence throws considerable light on the historiographical debate on the position of Britishness at the end of the twentieth century. Some commentators, such as Tom Nairn, have seen devolution as indicative of the crisis of Britishness, that granting powers to a parliament in Scotland was forced on English government by a popular nationalist campaign that will inevitably escalate its demands. ${ }^{13}$ This position is supported by others such as David Marquand and Christopher Harvie, who see British nationalism as belonging to a particular moment in imperial history. ${ }^{14}$ With the Empire deceased, they argue, the four nations of the British Isles are no longer united in common endeavour and are now inevitably finding their own paths in the context of European rather than British politics. Few would dispute that the importance of Britishness as a national identity has lessened yet it is important to recognise the continuing sense of common interest in the United Kingdom enabled by the adoption of multiple identities. As Arthur Aughey has argued, 'Belief in Britain may have diminished, but it has not yet disappeared,' and Vernon Bogdanor, the leading academic commentator on devolution, has presented the strong argument that 'Separatism [...] is by no means the necessary or even the most likely outcome of devolution to Scotland. ${ }^{15}$ Bogdanor takes a longer term historical view, pointing back to the Irish Home Rule crisis of the late nineteenth century, arguing that as Gladstone managed to accommodate diversity within Liberalism, so the pluralist

${ }^{12}$ ESRC DEVOLUTION, Devolution Programme Final Report, http://www.devolution.ac.uk/ 2006, accessed 30 August 2006.

${ }^{13}$ Tom NAIRN, After Britain, London: Granta, 1999.

${ }^{14}$ David MARQUAND, 'How United is the Modern United Kingdom?', pp. 277-291 in : Alexander GRANT \& Keith STRINGER (EDS), Uniting the Kingdom: The Making of British History, London: Routledge, 1995. Christopher HARVIE, 'The moment of British nationalism 1939-1970', Political Quarterly, vol. 71, 2000, pp. 328-340.

${ }^{15}$ Arthur AUGHEY, Nationalism, Devolution and the Challenge to the United Kingdom, London: Pluto, 2001, p. 182; Vernon BOGDANOR, Devolution in the United Kingdom, Oxford: OUP, 1979 (second edition 2001), p. 297. 
approach of Labour in the 1990s shows that 'a society may be held together through what Gladstone called "a recognition of the distinctive qualities of the separate parts of great countries". ${ }^{16}$ It does, of course, remain to be seen what happens in the future but the continuing ability of British parties - Labour, the Liberals and the Conservatives - to secure support from substantial majorities of the electorate in Scotland and Wales suggests that devolution has encouraged and not yet diminished a sense of Britain as a united polity. ${ }^{17}$ The United Kingdom has faced a range of challenges to its integrity since the 1960 s yet the very vagueness of what it means to be British has enabled a remarkably successful accommodation of the loss of Empire, of immigration, of European integration, and not least, devolution.

\section{References}

BIAGINI, Eugenio (ed). Citizenship and Community: Liberals, Radicals and Collective Identities in the British Isles, 1865-1931. Cambridge: Cambridge University Press, 1996. BIAGINI, Eugenio. Gladstone. Basingstoke: Palgrave, 2000.

BOGDANOR, Vernon. Devolution in the United Kingdom. Oxford: OUP, 1979 (second edition 2001)

ESRC DEVOLUTION. Devolution Programme Final Report. http://www.devolution.ac.uk/ 2006.

HITCHENS, Peter. The Abolition of Britain. London: Quartet, 1999.

HUTCHISON, IGC. Scottish Politics in the Twentieth Century. Basingstoke: Palgrave 2001.

MARQUAND, David. 'How United is the Modern United Kingdom?' pp. 277-91 in Alexander GRANT \& Keith STRINGER (eds), Uniting the Kingdom: The Making of British History, London: Routledge, 1995.

McLEAN, Iain \& McMILLAN, Alistair. State of the Union. Oxford: Oxford University Press, 2005

NAIRN, Tom. The Break-Up of Britain: Crisis and Neo-nationalism. London: New Left Books, 1977, (second edition, London: Verso, 1981).

NAIRN, Tom. After Britain. London: Granta, 1999.

SMITH, Anthony D. National Identity. London: Penguin, 1991.

REDWOOD, John. The Death of Britain? Basingstoke: Macmillan, 1999.

THATCHER, Margaret. 'Speech to Conservative Rally at Cheltenham', 3 July 1982, http://www.margaretthatcher.org/speeches/displaydocument.asp?docid=104989, accessed 13 August 2006.

THATCHER Margaret. The Downing Street Years. London: HarperCollins, 1993. WARD, Paul. Britishness since 1870. London: Routledge, 2004.

WARD, Paul. Unionism in the United Kingdom. 1918-1974, Basingstoke: Palgrave, 2005. WEIGHT, Richard. Patriots: National Identity in Britain 1940-2000. London: Pan, 2003.

\footnotetext{
${ }^{16}$ Vernon BOGDANOR, Devolution in the United Kingdom, Oxford: OUP, 1979 (second edition 2001), p. 298.

${ }^{17}$ For a recent and sensible analysis of the future, see Iain McLEAN \& Alistair McMILLAN, State of the Union, Oxford: OUP, 2005, which argues that 'it is more likely that the union state will lumber on, anomalies and all, for at least a few decades more' (p. 256).
} 